\title{
Multiple magnet ingestion resulting in small bowel perforation: a case report
}

\author{
Çoklu mıknatıs yutulmasına bağlı bağırsak perforasyonu: Olgu sunumu
}

\author{
Feryal GÜN, Tansel GÜNENDİ, Başak KILIÇ, Alaaddin ÇELİK
}

Foreign body ingestion is a common clinical situation that is primarily diagnosed by emergency clinicians. Most foreign bodies can be evacuated without difficulty. Although rare, magnets that reach the lower intestinal tract may cause complications such as intestinal fistula formation, perforation, volvulus or appendicitis. We report herein a two-yearold girl who was admitted to our department 3 days ago with abdominal pain and non-bilious vomiting. Upon admission direct abdominal roentgenogram revealed a foreign body consisting of multiple spheric parts bound together forming a circle in the lower quadrants of the abdomen. Her family, unaware of this ingestion, stated that a magnetic toy matching the object present on the plain radiograph was lost several days ago. Surgical intervention showed a magnetic toy in the proximal part of the ileum causing multiple perforations in the intestinal wall and the neighboring mesentery. The ileal portion containing the magnet toy was seen folded over itself forming a blind loop. The patient was discharged uneventfully in the 7 th postoperative day. Our case highlights a well known fact that foreign body ingestion in children may not have eye witnesses and should be taken into consideration when evaluating children with abdominal pain.

Key Words: Ingested magnets in children; ingested foreign body.
Yabancı cisim yutulması sıklıkla acil hekimlerinin karşılaştığı bir klinik durumdur. Çoğu yabancı cisim kendiliğinden çıkar. Ancak nadiren de olsa, distal intestinal sisteme ulaşabilen yabancı cisimler fistül, perforasyon, volvulus veya apandisit gibi komplikasyonlara yol açabilir. $\mathrm{Bu}$ yazıda, kliniğimize üç günlük karın ağrısı ve safrasız kusma şikayeti ile başvuran iki yaşındaki kız hasta sunuldu. Başvuru esnasında çekilen ayakta direkt karın grafisinde, karın sağ alt kadranda halka yapısında birbirine bağlı birden fazla sayıda yabancı cisim izlendi. Aile yabancı cisim yutulması ile ilgili herhangi bir öykü vermedi ancak karın grafisinde izlenen yabancı cisme benzer bir oyuncak mıknatısın birkaç gün önce evde kaybolduğunu belirttiler. Cerrahi girişimde proksimal ileumda bağırsak duvarında ve komşu mezenterde çoğul bağırsak delinmesine yol açan halka şeklinde mıknatıslı oyuncak izlendi. Bu yabancı cismin yer aldığı ileal parça yabancı cismin şeklini alarak kendi üstüne katlanmış ve o da halka şeklini almıştı. Hasta ameliyat sonrası yedinci günde sorunsuz olarak taburcu edildi. Bu olgu ile çocuklarda yabancı cisim yutulmasında herhangi bir şahitin olmayabileceği ve karın ağrılarının değerlendirilmesinde bu durumun da hatırlanması gerektiğinin bir kere daha altı çizilmelidir.

Anahtar Sözcükler: Çocuklarda yutulmuş mıknatıs; yutulan yabancı cisimler.
Foreign body ingestion is a problem commonly encountered in children, particularly in those aged between 6 months and 3 years. Ingested foreign bodies including coins, batteries, and pins reaching the stomach pass through the gastrointestinal tract spontaneously. On the other hand, multiple magnet ingestion may result in complications such as entero-enteric fistula or intestinal obstruction. Therefore, we report a very rare case of intestinal obstruction by enteroenteric fistula after the ingestion multiple magnets.

\section{CASE REPORT}

A two-year-old girl was admitted to our department with abdominal pain and non-bilious vomiting. Intravenous fluids and antibiotics were administered for three days however bilious vomiting developed afterwards. 


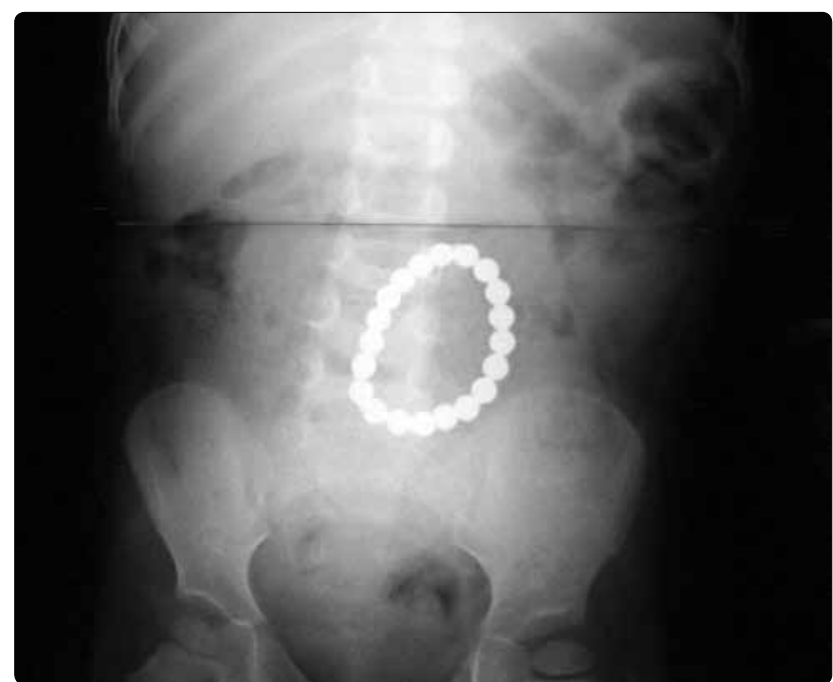

Fig. 1. Abdominal roentgenogram demonstrating a foreign body in the region of the lower quadrants.

On physical examination she looked dehydrated, and there was abdominal pain with diffuse tenderness in all quadrants, laboratory values were white blood cell: $16.100 \mathrm{~mm}^{3}$, C-reactive protein: $40.1 \mathrm{mg} / \mathrm{L}$, sodium: $133 \mathrm{mEq} / \mathrm{L}$, respectively. Abdominal roentgenogram showed a foreign body which consists of multiple spheric parts in a circular fashion (Fig. 1). Her parents admitted that a magnetic toy looking exactly the same as the roentgenogram disappeared several days ago.

The patient was hospitalized, oral intake was stopped, intravenous isotonic crystalloid fluids and antibiotic (sefazoline $100 \mathrm{mg} / \mathrm{kg}$ ) were administered. Serial abdominal X-rays were taken daily in which the magnets seemed to change place in each radiogram. On the 2nd day fluid resuscitation and antibiotic therapy seemed to improve the patient's clinical characteristics as she was mobilized and a slight relief in the abdominal pain was noted. On the 3rd day abdominal pain started again and this time bilious vomiting developed.

The patient was taken to the operation room and laparotomy was performed via an infraumblical midline incision. Upon exploration, foreign body was visualized in the proximal ileum causing perforation in the intestinal wall and the neighboring mesentery by forming a circle and leading to entero-enteric fistula.

It can be speculated that the patient had swallowed these magnetic pieces one by one and that the first and the very last piece of magnet opposed each other in the ileal segment closing the line and forming the circle. (Fig. 2). The foreign body was removed and the perforations were oversewn. She was discharged on the 7 th day postoperatively without any further complications.

\section{DISCUSSION}

Foreign body ingestion is usually detected in children between 6 months and 3 years of age and $80 \%$ of cases will have spontaneous passage of the foreign body, $10-20 \%$ require endoscopic removal, and $1 \%$ require surgical intervention. ${ }^{[1]}$

In some cases children swallow foreign bodies without an eyewitness and may not develop any symptoms at all. In a retrospective review, only $50 \%$ of children with confirmed foreign body ingestion were symptomatic. ${ }^{[2]}$

Once these swallowed objects pass the esophagus they will leave the gastrointestinal tract without difficulty and very few will necessitate surgical treatment. Foreign bodies that reach the stomach should be observed by serial abdominal radiograms. ${ }^{[3]}$

One magnet may not cause any clinical problem but things get complicated if multiple magnets are swallowed, resulting in gastrointestinal complica-
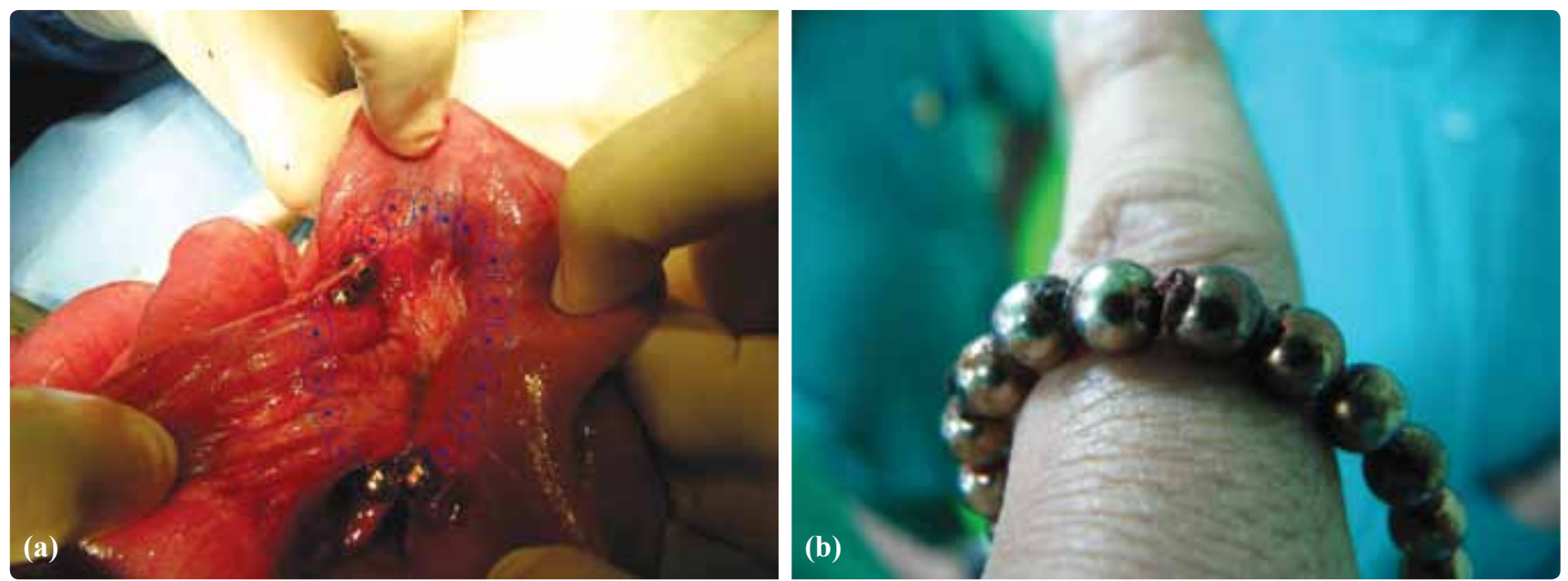

Fig. 2. (a) Illustration of foreign body on the original photo. (b) Note the pinched tissues between magnets. (Color figures can be viewed in the online issue, which is available at www.tjtes.org). 
tions, including intestinal fistula formation, leading to intestinal obstruction or perforation. ${ }^{[4,5]}$ A delay in the diagnosis facilitates necrosis of the intervening tissue, which will eventually lead to perforation and/or entero-enteric fistula formation and/ or bowel obstruction secondary to kinking, inflammatory reaction, and/ or internal herniation. ${ }^{[6,7]}$ In our case enteroenteric fistula was detected peroperatively.

Ingestion of multiple magnets in children may cause intestinal perforation in the early period. These cases should be monitored by close follow-up by repeated Xrays, and surgical intervention should not be delayed. ${ }^{[8]}$

Foreign bodies pass through children's gastrointestinal tract without their parents awareness before symptoms arise. Clinicians should be aware of risks associated with multiple magnet ingestion. When a child with a history of a foreign body ingestion is seen by a physician, a thorough history should be taken for a possible magnet ingestion. Upon appropriate medical support for deteriorated clinical condition, X-ray studies should be undertaken to determine the route of the magnet. If signs of bowel obstruction are present, a surgical approach is warranted to avoid further complications.
Conflict-of-interest issues regarding the authorship or article: None declared.

\section{REFERENCES}

1. Brown DJ. Small bowel perforation caused by multiple magnet ingestion. J Emerg Med 2010;39:497-8.

2. Nguyen LT. Foreign bodies. In: Puri P, Höllwarth ME, editors. Pediatric surgery. Berlin, Heidelberg: Springer; 2009. p. 206.

3. Butterworth J, Feltis B. Toy magnet ingestion in children: revising the algorithm. J Pediatr Surg 2007;42:e3-5.

4. Robinson AJ, Bingham J, Thompson RL. Magnet induced perforated appendicitis and ileo-caecal fistula formation. Ulster Med J 2009;78:4-6.

5. Nui A, Hirama T, Katsuramaki T, Maeda T, Meguro M, Nagayama $M$, et al. An intestinal volvulus caused by multiple magnet ingestion: an unexpected risk in children. J Pediatr Surg 2005;40:e9-11.

6. Fenton SJ, Torgenson M, Holsti M, Black RE. Magnetic attraction leading to a small bowel obstruction in a child. Pediatr Surg Int 2007;23:1245-7.

7. Alzahem AM, Soundappan SS, Jefferies H, Cass DT. Ingested magnets and gastrointestinal complications. J Paediatr Child Health 2007;43:497-8.

8. Sahin C, Alver D, Gulcin N, Kurt G, Celayir AC. A rare cause of intestinal perforation: ingestion of magnet. World J Pediatr 2010;6:369-71. 